\title{
Fra et »konsultations«værelse i Chicago
}

\author{
Af Jakob Balling
}

Det er et bemærkelsesværdigt tegn på den stigende internationale interesse for Grundtvig, at der i sommeren 1995 kunne afholdes en faglig konference om ham med deltagelse fra USA, Storbritannien og Danmark i den amerikanske lutherske kirkes (ELCA) hovedkvarter på toppen af et højhus i udkanten af Chicago. Mødet var kommet i stand gennem et samarbejde mellem ELCA og Center for Grundtvigstudier ved Århus universitet; og dets officielle betegnelse: "Consultation «, angiver præcist den impuls, der har ført til dets forberedelse og afholdelse: et fra flere nationale hold ytret $\emptyset$ nske om udveksling af indtryk og erfaringer blandt Grundtvigkendere og Grundtviginteresserede med vidt forskellig faglig såvel som national baggrund, og under udnyttelse netop af denne forskel i baggrund og synsvinkel. I den forstand kan mødet således siges at udgøre en fortsættelse af tidligere sammenkomster på Sandbjerg, i Durham og i Århus.

Blandt de hen ved 40 deltagere i det 4 dage lange møde (19.-23. juli) bidrog 9 med længere indlæg, spændende over en særdeles bred skala af emner. Ud over dem blev der af danske kendere leveret en række mindre bidrag med henblik på orientering af amerikanere og briter om igangværende danske initiativer; og et enkelt bidrag - uden for alle grupperinger, men af betydning som »modlyskaster « - handlede om Søren Kierkegaards ideer om kirken (ved Bruce Kirmmse, Kierkegaard-Centret, København).

De længere bidrag, som også udløste livlig og lærerig diskussion under gemytlige former, kan siges at falde $\mathrm{i}$ fire hovedgrupper, alt efter den overordnede tematik. Tre bidrag diskuterede hver for sig forholdet mellem Grundtvig og én anden teolog, nemlig henholdsvis Johann Adam Möhler (ved R. William Franklin, General Theological Seminary, New York City; teksten er bragt i sin helhed på de foregående sider); Joseph Sittler (ved Philip Hefner, Lutheran School of Theology, Chicago); og Regin Prenter (ved Michael Root, Institute for Ecumenical Research, Strasbourg). I en gruppe på to bidrag behandledes delaspekter af Grundtvigs forfatterskab, dvs. henholdsvis hans politiske tænkning og kvindesyn (ved Penny Gill, Mount Holyoke College, South Hadley, Massachusetts) og hans gudstjenestesyn (ved A.M.Allchin, Bangor). En tredje gruppe betragtede Grundtvigs virkningshistorie, henholdsvis blandt danske immigranter i Amerika 
(ved Axel C. Kildegaard, Circle Pines, Minnesota) og i en række overs $\varnothing$ iske landes folkeoplysningsbevægelser (ved Lilian Zöllner, Nornesalen, Ollerup). Endelig diskuteredes, i hvad der kan betegnes som en fjerde gruppe, Grundtvigs forhold til angelsaksisk litteratur (ved S.A.J.Bradley, University of York) og hans relevans for diskussionen om en poetisk-teologisk tradition i europæisk åndsliv (ved Jakob Balling, Århus universitet).

Det ligger i sagens natur, at samtlige de foredrag, der holdtes af ikke-danskere, varetog en af mødets vigtigste opgaver: at kaste fremmed lys på Grundtvig. Men to af foredragene havde dette som direkte formål ved hver for sig at diskutere det idémæssige forhold mellem Grundtvig og en ikke-dansk tænker. Med henblik på lidt nærmere orientering herom skal disse to indlæg præsenteres i påkrævet korthed i det følgende.

Intet af dem tilsigtede en udredning af »påvirkninger « mellem de respektive teologer og Grundtvig - i så fald havde man lynhurtigt kunnet gå over til andre emner! I begge tilfælde var det, der søgtes påvist, et slægtskab eller et analogiforhold mellem på den ene side de problemer, disse tænkere tog op og de løsninger, de forsøgte sig med, og på den anden side Grundtvigs problemer og løsningsforsøg, alt under skyldigt hensyn til de forskelle i miljø, tidsatmosfære og tænkestil, der satte deres præg på spørgsmål og svar, og ikke mindst til den nutidsrelevans, der knytter sig til de respektive emner.

William Franklin tog i sit foredrag: "Johann Adam Möhler and N.F.S. Grundtvig: the Bridge of Romanticism« den opgave op, at undersøge det idé- og situationsmæssige forhold mellem Grundtvig og hans samtidige, Möhler, den tyske romersk-katolske teolog. Möhler var banebryder for en kirketænkning, der var stærkt kritisk over for den eftertridentinske katolske ekklesiologi med dens eftertryk på kirkens karakter af hierarkisk, quasistatslig institution under umyndiggørelse af lægfolket, og som søgte inspiration for en katolsk fornyelse i patristisk tænkning om kirken som et folk, forenet i gudstjenestens fælles erfaring, formidlet på modersmålet. Denne stillingtagen på en indrekirkelig front - fortsat, som Franklin påpegede, i den teologi, der i vort århundrede førte frem til Andet Vatikankoncil - indgik hos Möhler en særpræget forbindelse med nogle konklusioner, han drog af sin oplevelse af den moderne sækularismes og den prøjsiske statsligheds og nationalismes trusler mod kristen menneskelighed. Som værn mod dem var kirkens institutionskarakter og dens overna- 
tionale ledelsesstruktur noget, der skulle fastholdes jævnsides med udarbejdelsen af den nye forstålse af kirken som et levende og myndigt folk. Disse tendenser er, gjorde Franklin gældende, altsammen noget, der må forstås som udtryk for almene tendenser og aspirationer i tiden, ting der fandt udtryk i den romantiske bevægelse som helhed, og mere specifikt i tysk protestantisk teologi. Bemærkelsesværdigt nok var Möhler dybt påvirket netop af de bevægelser i tysk protestantisme, som tegnedes af folk som Schleiermacher og Neander, foruden af Schellings romantiske filosofi. Det var nu Franklins påstand, at også Grundtvig hørte hjemme i denne europæiske bevægelse for et nyt syn på kirken og en kristen stillingtagen til moderniteten; han fandt den bekræftet gennem en analyse af de konsekvenser, Grundtvig drog af sin mageløse opdagelse, gennem hans begreb om lægfolksmyndighed og folkelig kultur. Han fandt iøvrigt, at fænomenet var lærerigt for overvejelser over nutidige økumeniske bestræbelser. - En dansk betragtning af disse sammenhænge ville sandsynligvis placere diverse akcenter anderledes end Franklin, men ligesom andre ikke-danske bidrag på mødet godtgjorde hans indlæg på overbevisende måde, at værdifulde impulser kan vindes ved at gå til Grundtvig »udefra«.

I sit foredrag: "Theology and Creation: Joseph Sittler and N.F.S. Grundtvig « beskæftigede Philip Hefner sig med det interessefællesskab, han fandt kunne konstateres mellem Grundtvig og den amerikanske lutherske teolog og økumeniker fra vort århundrede, Joseph Sittler. Han interesserede sig også for nogle lærerige forskelle, delvis bestemt af den ændrede tidssituation, og ikke mindst for de nutidsperspektiver, læsningen af de to teologer åbnede.

Afgørende for fællesskabet var ifølge Hefner de to tænkeres fundamentalt skabelsesteologiske udgangspunkt for refleksion over det kristne frelsesbudskab. Over for den tendens, der dominerede deres respektive »samtider «: tendensen til at se det konkret forhåndenværende menneskeliv som det, frelsen var en frelse $u d$ af, stillede Grundtvig og Sittler hver på sin måde den påstand, at netop den situation - »tingene som de er « - er den, frelsen finder sted i og bruger som sit middel til genløsning og genoprettelse. Enhver anden idé om frelsen, mente Grundtvig, var nødt til at drive frelsesteologi via den fortvivlelsesudvej, at »for Gud er alting muligt«. Og Sittler på sin side sagde: »En kristen teologi kan ikke gå fra nåde til natur; inkarnationen kræver, at den relaterer nåden til naturen på en sådan måde, 
at Guds nærvær som nåde i naturen ikke i princippet udelukkes «. Skabelse er nøgleordet for begge tænkere; hvis dogmet om skabelse "af intet" skal tage alvorligt og ikke bare indskrænkes til en teori om en fortidig akt, så betyder det, at den verden, vi lever i, defineres som noget, der har sin grund og sin eksistens i Guds skabervilje og ikke i noget som helst andet. Dermed er også sagt, at verden defineres som nådesudtryk, som skueplads for Guds nådige nærvær som skaber, opholder, frelser og fornyer. »Nåden«, sagde Sittler, »kom med Jesus Kristus, men den var ikke skabt af ham «.

En videre overensstemmelse fandt Hefner i begge tænkeres tilsvarende sans for den foreliggende verdens foranderlighed og for, at skabelsen altså ikke bare er »af intet«, men »fortsat«. Netop dette fandt han udtrykt i Grundtvigs begreb om konkrete og gennem tiden skiftende folkeligheder som det sted, hvor guddommelig handlen manifesterer sig i stedse skiftende former. Og hvad Sittler angår, lå en lignende tankegang bag hans skarpe kritik af en luthersk teologi, der så sin væsentlige opgave i »bevarelse, klargørelse og overførelse« af en konfessionel fortidsarv. Men iøvrigt gælder en væsentlig del af Sittlers opmærksomhed vedrørende forandringsperspektivet, og behovet for åbenhed og lydhørhed over for det, noget andet. Nemlig den menneskets indfældethed i og ansvar over for den ikke-menneskelige natur, som vor samtid er blevet stadigt mere bevidst om. Denne erkendelse i den kulturelle almenhed kalder, mener Sittler, på den teologiske erkendelse, at begreberne »Lov « og »Evangelium « ikke blot har med privat individuel synd og tilgivelse at gøre, men også med f.eks. »vor måde at omgås Michigansøen på«.

Med det forbehold, at Grundtvigs natursyn måske skal søges i uoversatte tekster, mente Hefner at kunne konstatere en væsentlig forskel mellem de to netop på dette punkt, al den stund Grundtvigs hovedinteresse, når talen er om Guds skaber- og frelservirke $\mathrm{i}$ foranderlighedens verden, er (menneske)historisk. Hvordan denne forskel i givet fald nærmere skal karakteriseres, og hvilke konsekvenser, der skal drages af den, er et spørgsmål, Hefner overlod til videre undersøgelse og drøftelse. Det samme gælder den, der åbenbart består mellem Grundtvigs forankring i et førkritisk forhold til bibelske studier og Sittlers åbenhed for den kritiske videnskab.

Foredraget sluttede med skitsemæssige betragtninger over de Grundtvig-Sittlerske erkendelsers aktualitetsinteresse. For en dansk tilhører knyttede der sig herunder størst interesse til Hefners kritiske 
bemærkninger om et amerikansk teologisk og kirkeligt miljø, der nok interesserer sig for de teologiske perspektiver $\mathrm{i} »$ tredjeverden «s- og mindretalsproblemer o.l., men lader den "grundtvigske« opgave ligge: at give det »almindelige« amerikanske samfund og dets kulturelle og sociale traditioner en teologisk gennemlysning. Her såvel som i foredraget som helhed bekræftedes det på stimulerende vis, at det, der var på tale, var ting, der lå foredragsholderen selv på sinde $\mathrm{i}$ hans egen aktuelle situation som teolog og kirkemedlem. Det bekræftedes også, at denne situation ikke i alle henseender stemmer overens med den danske.

Netop at Grundtvig kunne læses som en, der talte meningsfuldt ind $\mathrm{i}$ en betydeligt anderledesartet folkelig, kulturel og idéhistorisk tradition, var muligvis noget, der ville have overrasket ham selv. Men det var en af de vigtigste ting, der var at lære på mødet. Belæringen forventes fortsat på senere møder. 